\title{
Crude Oil and the Libyan Economy
}

\author{
Abdulrazag Mohamed Etelawi ${ }^{1}$, Keith A Blatner ${ }^{2} \&$ Jill McCluskey $^{3}$ \\ ${ }^{1}$ Department of Mathematics and Statistics, Washington State University, USA \\ ${ }^{2}$ School of the Environment, Washington State University, USA \\ ${ }^{3}$ School of Economic Sciences, Washington State University, USA \\ Correspondence: Keith A. Blatner, School of Economic Sciences, Washington State University, Pullman, WA \\ 99164-2812. Tel: 509-335-4499. E-mail: blatner@wsu.edu
}

Received: February 9, 2017

Accepted: March 7, 2017

Online Published: March 15, 2017

doi:10.5539/ijef.v9n4p95

URL: https://doi.org/10.5539/ijef.v9n4p95

\begin{abstract}
Oil is the primary source of income in the Libyan economy; hence, it is important to more fully understand the economic factors associated with this sector of the economy. We applied a recent growth theory model to develop a better understanding of the relationship among capital, labor, domestic consumption of oil, oil exports and gross domestic product (GDP) in the Libyan economy. A log linear model was estimated using annual data for the period 1980 to 2012. All of the coefficients were significant at the 0.05 level except the log of labor, which was significant at the 0.0613 level. The signs associated with the variables were consistent with economic theory. The adjusted $\mathrm{R}$ square was 0.912 indicating that approximately 91 percent of variation in GDP was explained by the independent variables. There was only limited multicollinearity in the model as all Variance Inflation Factors (VIF) values were less than 10. Breusch Pagan and Anderson-Darling test results indicated a constant variance and that the errors were normally distributed, respectively. Similarly, the Durbin-Watson statistic indicated an absence of autocorrelation at the 0.05 level. The resulting elasticities were positive and strongly inelastic, indicating that large changes in each of the variables would be required to dramatically increase GDP. Nevertheless, it is clear that oil will continue to play a leading future economic growth and development.
\end{abstract}

Keywords: Libya economy, production, growth theory, crude oil, economic development, Gross Domestic Product (GDP)

\section{Introduction}

Libya is a developing country in North Africa, which lies south of the Mediterranean Sea east of Algeria and Tunisia, and west of Egypt and Sudan. The Libyan economy is almost totally dependent on hydrocarbon production, with crude oil and natural gas representing about 96 percent of all government revenue. In 2012, it provided approximately 98 percent of all export revenue. In 2012, at least 79 percent of all government revenue received resulted from exports of crude oil or approximately $\$ 4$ billion per month (EIA, 2013).

Libya has the largest oil reserves in Africa. Libyan oil is a "sweet" crude, which means that it has a low percentage of impurities - a very desirable attribute. It is estimated that Libya has total recoverable reserves of approximately 46 billion barrels of oil, or about 3.4 percent of total international reserves and the ninth largest reserves in the world. Oil production in recent years peaked in October 2012 at 1.5 million barrels per day. Oil production dropped sharply with over throw of previous government and the ongoing civil strife in the country in 2013. Average daily production for the first have of 2016 totaled 332,000 barrels per day. Nevertheless, oil remains the key to future growth in the economy (Ycharts, 2016).

Mills (2008) reports that Libya is an important OPEC (Organization of Petroleum Exporting Countries) producing country; however, Libya's potential as a supplier has been hindered by sanctions and political turmoil. These and other factors resulted in production falling from a peak of 3.4 million barrels per day in 1970 to 1.0 million barrels per day in 1987. In 2002 and 2006, the oil production reached to 1.4 and 1.8 million barrels per day, respectively. With the end of the sanctions in September 2004, international companies began investing in Libyan oil production and brought in new technology and skilled labor.

Before the revolution in 2011, Libya's National Oil Corporation (NOC) indicated that it needed to use more advanced oil recovery techniques in order to increase oil production capacity in maturing oil fields. The NOC 
demonstrated that it was possible to increase capacity by about 775,000 barrels per day from existing oil fields.

Libyan oil production and exports were again disrupted for most of 2011 due to the revolution. Production was again crippled again 2013, when protests closed some of the oil fields, loading facilities, and pipelines. The revolution in 2011 decreased natural gas and oil production resulting in an economic collapse, with real GDP contracting approximately 62 percent in 2011. In 2013, production decreased almost 14 percent (EIA, 2013).

Libyan domestic oil consumption depends heavily on domestic production from its refineries. Libya has five major refineries with an estimated capacity of about 378,000 barrels per day (EIA, 2013). The NOC has current plans for increasing refinery capacity. Libya's economy consumed about 170,000 barrels per day of petroleum based products in 2012. Libya exported the remaining oil related products from its refineries during the same year (EIA, 2013).

\section{Related Works}

Previous studies have analyzed crude oil and economic performance in the petroleum developing countries and non-petroleum based countries. Obviously different factors directly or indirectly affect economic growth as measured by the Gross Domestic product (GDP). Population is also a significant factor in explaining changes in GDP, as well as political factors. Kiria (2013) states that the International Monetary Fund (IMF) utilizes three criteria to distinguish between developing and developed countries: these include "One, per capita income level; two, export diversification whereby oil exporters that have high per capita GDP would not make the advanced classification, because around $70 \%$ of its exports are oil; and three; degree of integration into the global financial system directly or indirectly" (p. 149).

Adjemian et al. (2010) argues that endogenous growth theory emphasizes distortions in fiscal instruments, which in turn may affect the consistency of investments in skilled labor, knowledge, and innovation needed for increased economic growth. They point out that the availability of skilled labor increases economic growth, while a high unemployment rate leads to low economic growth in the long run.

Consumption and production plays a major role in economic growth. Noor and Siddiqi (2010) state that energy is a major driver underlying economic growth, because different production and consumption activities are tied directly to energy use as essential inputs. On the production side various economists beginning with Adam Smith considered labor, land, and capital the major inputs needed for many economic activities. These inputs were particularly important for the agricultural economies of the $17^{\text {th }}$ and $18^{\text {th }}$ centuries. Industrial growth added a fourth major input energy.

Shaari et al. (2013) argues that energy consumption has a major effect on economic growth. Yuan et al. (2008) demonstrates that traditional neo-classical thinking deals with energy as the intermediate input, and capital and labor as primary factors suggesting a neutral role for energy in production. Generally, changes in energy consumption affect those economies that are heavily dependent on energy use. The authors point out that labor, capital, and energy consumption are the major factors underlying GDP growth.

Other studies indicate that the relationship between economic growth and consumption maybe indirect or mixed. Asafu-Adjaye (2000) emphasizes that there is an indirect relationship between income or growth and consumption for some developing countries, because each country has its own unique circumstances. Asafu-Adjaye (2000) further emphasizes that high energy demand is a result of high levels of economic growth and vice versa. Conversely, Mahadevan and Asafu-Adjaye (2007) argue that the relationship between economic growth and energy consumption is mixed. Increasing GDP may affect consumption in two different ways. First, households may choose to spend the extra income earned on energy dependent activities such as transportation and computers. Alternatively, economic growth may expand other manufacturing activities and thus energy becomes a necessary input in different production operations in an industrial economy.

Other studies indicate that the relationship between economic growth and consumption is not as clear in some developing countries owing to the lack of economic accounting systems. Karanfil (2008) demonstrates that developing countries usually do not record economic activity correctly, so the linkage between consumption and economic growth as measured by GDP may be inaccurate. The author also points out the relationship between growth and energy consumption takes place in the long run. Lee (2005) illustrates energy consumption and economic growth has been a popular issue of debate in the environmental and economic development literature. The author further explains that evidence suggests a relationship between energy consumption and GDP, while stressing that GDP is affected by energy consumption in some of developing countries in both the short and long term. He goes on to discuss that energy conservation may negatively affect the economic growth in these countries regardless of being either transitory or permanent. 
Sari and Soytas (2007) argue that energy is a necessary factor for any production process. They further point out that empirical evidence indicates that in some countries, energy may be more important than labor, because labor is a cheaper input. The authors also explain that the evidence indicates it is possible to sustain a high rate economic growth rate in countries in the long run, if they rationalize fuel consumption in other sectors of the economy.

Different studies indicate that the relationship between economic growth and exports may be direct or indirect, but increasing exports has a positive effect on economic growth. Mehrara and Firouzjaee (2011) show that in the early 1960's policymakers and researchers investigated the relationship between exports and economic growth. The researchers examined the relationship to determine whether a country should increase exports for increased economic growth or should encourage economic growth from the outset in order to increase exports. The authors concluded that export development, exit and free entry are the main factors underlying economic growth. For instance, foreign competition causes firms to prefer a more efficient allocation of resources, scale economies, motivating creativity and innovation. Also, exports may increase imports of intermediate goods, which in turn results in increased output growth and capital accumulation.

Vohra (2001) discusses the relationship between exports and GDP in economic development. Many empirical studies conclude that there are several benefits of exports on GDP such as increased specialization, better capacity utilization, and increased scale. Shirazi and Manap (2005) state export-led growth may increase economic growth for a period of time and suggests export expansion as a mechanism for promoting better allocation of resources, capital formation, increased employment, and the use of technology for efficient of production.

Maneschiold (2008) also emphasizes that many empirical studies suggest that there is a strong relationship between economic growth and exports. It is important to note that the major purpose of exports is to improve economic growth. The author claims that attention is gradually being given to the idea that the best way to achieve economic growth is through increased exports and openness, rather than through import substitution. Shifting from import substitution to increased exports and openness implies the importance of a more liberalized and more competitive shift in trade and industrial policies for developing countries such as Libya.

Yousef (2013) reported that increasing domestic consumption of refined oil will impact Libyan exports. He suggests that policy makers should increase the price of some refined products such as gasoline and diesel. Ali and Harvie (2013) state that oil sector revenue increased the benefits to the non-oil sector through investment in human resources, economic growth, and the employment rate. Ali and Harvie (2013) further demonstrate the oil sector in Libya is very important, not just for Libya's economy, but also for the European Union and the world economy.

Sultan and Haque (2011) explain there are three interrelated variables important for economic growth: investment, production, and exports. Investment leads to production, production results in economic growth and increased exports, while increased exports also contributes to growth. Growth in developing countries is often dependent upon imported capital goods, but it is difficult for these countries to continue import capital goods, unless their exports are increased to obtain needed foreign exchange. The authors state that investment is led by exports and promotes more investment, which in turn, leads to further growth.

Ali and Harvie (2013) state the exchange rate for Libyan dinar is also a major factor affecting real income. Increasing oil revenue may also influence the non-oil trade of payment. The authors emphasize that investment is one of the most important factors needed to improve the Libyan economy. It is demonstrated that the Libyan economy is no exception to other oil developing and non-oil developing countries.

Fluctuating oil prices in the international market also have a large impact on economic growth, exports, imports and labor, which in turn affect economic growth. Akram and Mortazavi (2011), Doğrul and Soytas (2010), and Yanagisawa (2012) state the effect of oil prices on economic growth has received considerable attention in the economic literature since the early 1980 's. This is particularly true for developing countries, because they do not use energy efficiently. They explain that developing economies lack alternative energy sources compared to developed economies and have a limited ability to deal with financial crises resulting from high oil import costs.

There is a strong relationship between oil prices and economic growth, where prices have a negative relationship with the GDP growth for oil importing countries and a positive relationship with unemployment. The primary effect of rising oil prices on GDP is dependent on characteristics of each individual country. Moreover, these characteristics may influence the relationship of imported oil to GDP, exports as a portion of GDP, and oil exports to other countries. It is understood that in the short run, when oil prices increase, imported oil is used at the same rate, because the demand for oil is inelastic relative to price. The author also notes that the general impact of rising oil prices may increase profits and wages, while using subsidized oil for local consumption. However, for non-oil countries, rising oil prices may lead to reduced savings and a reduction in the purchase of other goods and services. 
Berument et al. (2010), Alimi and Muse (2013), Nkomo (2006), and Salah (1990) demonstrate that it is essential to focus on international markets in order to achieve a viable development strategy aimed at increasing productive capacity. Fluctuations in world prices affect government revenues and development projects for economic growth and employment. Libya's GDP is directly affected by world oil prices. The author emphasizes that the non-oil sector in Libya is also influenced by fluctuating oil prices and that high oil prices lead to increased revenue as well as more financing for increased imports. Libya's economy has a strong positive relationship between the price of oil and economic growth.

Similarly, increasing oil prices have a severe negative impact on the economies of oil importing countries. It was pointed out that oil price increases have reduced the national output, increased import expenses, and shifted the economy to a lower level of growth due to the higher cost of oil products. It is noted that high oil prices creates suffering for both a consumer and a producer in this case. When the price of oil increases, both the consumer and the producer have limited flexibility for reducing their use for oil and oil products, especially in the short run.

Finally developing countries have higher unemployment and a higher rate of economic growth compared to developed countries. Dallago (2013) explains that when unemployment increases, public revenue tends to decrease and public expenditures are under pressure.

\section{Research Methodology}

Amadi and Amadi (2014) state that growth theories prior to Romar (1986) were primarily focused on exogenous factors such as technology. One of these growth theories was the Solow Growth Theory (Solow, 1956), also known as the "exogenous growth theory," because technology is an exogenous factor in the determination of economic growth. The basic assumptions underlying Solow model include: constant returns to scale with diminishing returns to capital and labor, a competitive market equilibrium as well as a constant return to savings. The primary point of the Solow model is that an economic model is based on long-term economic growth and the rate of technological progress is an external factor.

Amadi and Amadi (2014) emphasize that the endogenous growth theory was developed in reaction to the limitations of the exogenous (neoclassical) growth theory. The endogenous theory or "new growth theory" was first applied in 1986 (Romar, 1986), where the authors used knowledge as input to the underlying production function. The goal was to emphasize that endogenous productivity growth or technical progress explains long-term growth. The primary factors in this model are: increasing returns to scale, the importance of human capital (skills, training and knowledge) and new technology. They also posit that long-term growth and knowledge are non-rival goods, and finally the primary source of technological progress is private investment in research and development.

Gbadebo et al. (2009) argue that savings also affects long-term growth due to the increased investment in human capital, development and research. Their model has successfully predicted which economy will grow as long as there are new ideas or technology. The Gbadebo et al. (2009) production function may be expressed as:

$$
Y=A(R) f(R i, K i, L i)
$$

where: Y refers to output, A refers to knowledge from research and development R, Ri refers to technology, $\mathrm{L}$ refers to labor, and $\mathrm{K}$ refers to capital. The model can be restated as:

$$
Y=f(K . L, E) \text { where } \mathrm{E} \text { refers to energy. }
$$

or:

$$
R G D P=f(G f c f, L a f, C o c, E t c, C l c)
$$

Where: RGDP is Output,

Gfcf $=$ Gross fixed capital formation,

Laf $=$ Labor force,

$\mathrm{Coc}=$ Crude Oil consumption,

Etc $=$ Electricity consumption and

$\mathrm{Clc}=$ Coal consumption.

The authors rewrite the above equation as:

$$
R G D P_{t}=\alpha_{0}+\alpha_{1} G f c f_{t}+\alpha_{2} L a f_{t}+\alpha_{3} \operatorname{Coc}_{t}+\alpha_{4} E t c_{t}+\alpha_{5} \operatorname{Clc}_{t}+U_{t}
$$

where: $\alpha_{1}>0, \alpha_{2}>0, \alpha_{3}>0, \alpha_{4}>0, \alpha_{5}>0$.

Odularu (2008) emphasizes that growth theory has evolved over the years. Odularu applied the economic growth theory model to Nigeria's economic performance. Odularu also emphasized that the model may be used for crude 
oil and economic performance in oil countries like Nigeria. The economic model is

$$
R G D P=f(L, K, D C, E)
$$

where:

$$
\begin{aligned}
& \mathrm{L}=\text { Labor } \\
& \mathrm{K}=\text { Capital } \\
& \text { DC refers to Domestic Consumption and } \\
& \text { E refers to Exports. }
\end{aligned}
$$

Dada (2011) states that Odularu (2008) analyzed the relationship between economic performance and the oil sector in Nigeria, was similar to the work by Adebipe (2004). This work is important because Adebipe was able to estimate GDP growth in Nigeria, which in turn allows policy maker to make more informed decisions regarding consumption and investment in oil sector as well as other economic sectors. Their finding, using ordinary least squares (OLS) and time-series data for the period 1970 to 2005, found a positive relationship between oil consumption and exports in the improving Nigerian economy. Oil prices also had a positive effect on national income. The study indicated there was a positive relationship between the price of oil and government expenditures. Exports of crude oil were insignificant in this case. Dada (2011) also showed that different factors other than exports control economic performance on the oil sector in Nigeria such as, investment, corruption, openness and terms of trade.

It is possible to apply Odularu's (2008) model to Libya, because in both countries oil exports, consumption, and exports levels are very similar. In addition, both countries are OPEC members, are located in the same region in Africa, oil is the primary source of their national income is oil, they both have a high unemployment rate, and are both developing countries. Hence, we chose to apply Odularu's (2008) model as noted above in this analysis.

Data for this analysis were obtained from a variety of sources including: World Bank, the United Nations, Central Bank of Libya, Organization Petroleum Export Countries (OPEC), United States Energy Information Administration (EIA), Central Intelligence Agency (CIA), Index Mundi, various papers, and books. Table 1 summarizes the data used in this study. All monetary data are presented in current dollars. Monetary data presented in Table 2 are expressed in 2005 constant dollars. The minimum production cost per barrel of $\$ 2.61$ occurred in 1989, while the highest cost of production per barrel was $\$ 9.26$ dollars in 1985 , for an average of $\$ 4.98$ per barrel (Table 5). The lowest production was 180.53 million barrels in 2011, while the highest level occurred in 2008 at 647.80 million barrels. Production increased on average throughout the entire study period rising to 507.95 million barrels.

Capital increased from $\$ 1.11$ million dollars in 1989 to $\$ 4.91$ million in 2008 (Table 1). Capital increased an average of $\$ 2.50$ million per year. The price of oil was $\$ 13$ per barrel in 1986. The highest price occurred in 2011 at $\$ 112.89$ per barrel. Oil prices increased an average of $\$ 37.32$ per barrel per year. The lowest exchange rate $\$ 0.28$ per one Libyan dinar occurred in 1990, 1991, and 1992, while the exchange rate occurred in 2004, 2005, and 2006 was $\$ 1.31$ per one dinar. The exchange rate increased an average of $\$ 0.65$ per one dinar per year over the period of analysis. The minimum number of workers (labor) occurred in 1997 at 1.20 million, while the maximum number of workers also occurred in 1996 at 2.61 million.

The maximum value of oil exports oil occurred in 2008 was $\$ 60.68$ billion, and the minimum value was $\$ 5.28$ billion in 1987. Oil export prices increased an average of $\$ 17.63$ billion per year. Local oil consumption increased from 36.00 million barrels in 1980 to 97.70 million barrels in 2007, for an average of 66.34 million barrels per year. GDP increased from $\$ 21.91$ billion in the year 2002 to $\$ 95.80$ billion in 2012 .

\section{Research Findings and Results}

The model that was estimated is represented as follows:

$$
Y_{i}=B_{0}+B_{1} X_{1}+B_{2} X_{2}+B_{3} X_{3} \quad B_{4} X_{4}+\varepsilon_{I}
$$

where one assumes that $\varepsilon \sim \mathrm{N}\left[0, \sigma^{2}\right]$. The functional form of the estimated equation is the following:

$$
\text { Ln RGDP }=\beta_{0}+\beta_{1} \operatorname{Ln} K+\beta_{2} \operatorname{Ln} L+\beta_{3} \operatorname{Ln} D C+\beta_{4} \operatorname{Ln} E+\varepsilon
$$

The model was expressed in logarithmic form for estimation after reviewing the data.

The model was estimated using OLS. The results are presented in Tables 3 and 4. All of the coefficients were significant at the 0.05 level except the log of labor, which was significant at the 0.0613 level. The signs associated with the coefficients were all positive and consistent with the previously presented theory. The R-square was 0.924 and adjusted R square of the model was 0.912 indicating that approximately 91 percent of variation in GDP was 
explained by the independent variables. There was only limited multicollinearity in the model as all Variance Inflation Factors (VIF) values are below 10.

Applying the Breusch Pagan test, yielded a p-value of 0.1894 which is greater than 0.05 , indicating the variance was constant. Similarly, based on the Anderson-Darling test, the errors are approximately normally distributed, since the p-value of 0.3743 greater than 0.05. The Durbin-Watson D statistic was 2.41. Since the Durbin-Watson D statistic was greater than the upper bound of the test statistic (1.730) at the alpha 0.05 level, we can also conclude that the error terms are independent. Therefore, we can conclude that since errors are normally distributed and have constant variance, the results from the OLS regression are valid, (Kutner et al., 2004).

Based on the previously noted theory and results of the model estimation we can conclude the independent variable of Capital, Labor, Domestic Consumption and Exports are all positively correlated with increased GDP. Given the log linear functional form of the model, the parameter estimates presented in Table 4 are also the elasticities associated with the independent variables. It is apparent that GDP growth resulting from increased oil production is inelastic, but positively correlated with respect to additional units of capital, labor, domestic consumption and oil exports or simply large increases in domestic consumption, exports, capital and labor are required to dramatically increase GDP. For example a one percent increase in exports will result in 0.13 percent increase in GDP, while a one increase in domestic consumption will result in a 0.22 increase in GDP.

Table 1. Calculation the terms in current US dollars

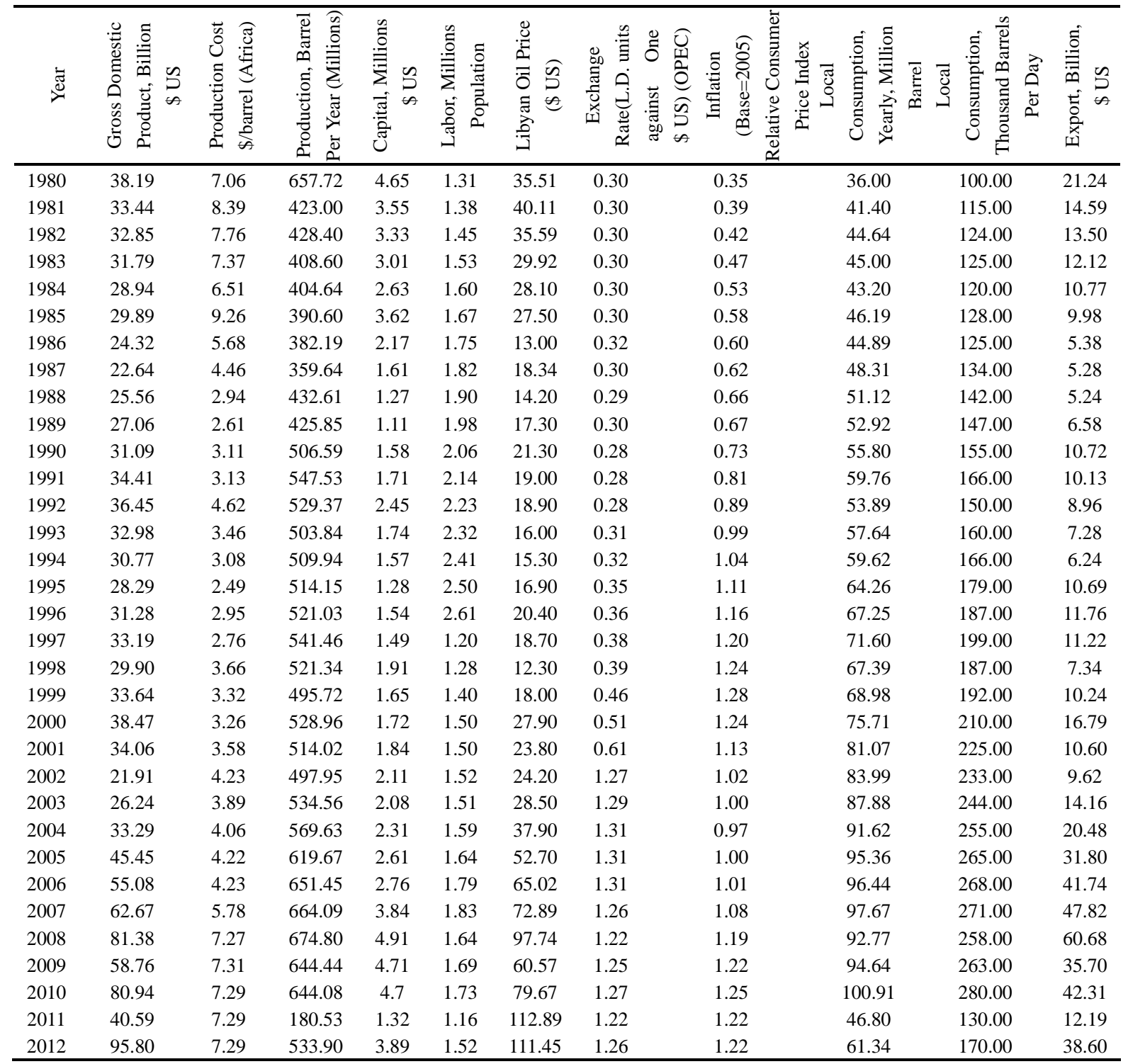

Sources: See Appendix A. 
Table 2. Calculation the terms in constant 2005 US dollars

\begin{tabular}{|c|c|c|c|c|}
\hline 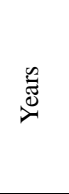 & 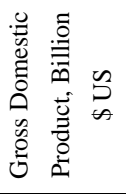 & 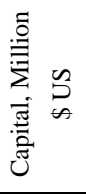 & 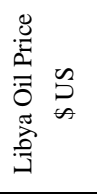 & 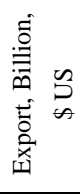 \\
\hline 1980 & 40.48 & 1.61 & 12.3 & 61.33 \\
\hline 1981 & 32.71 & 1.37 & 15.45 & 37.88 \\
\hline 1982 & 33.63 & 1.41 & 15.11 & 31.80 \\
\hline 1983 & 32.80 & 1.41 & 14.05 & 25.81 \\
\hline 1984 & 31.15 & 1.39 & 14.84 & 20.40 \\
\hline 1985 & 33.74 & 2.09 & 15.85 & 17.31 \\
\hline 1986 & 29.91 & 1.29 & 7.74 & 9.03 \\
\hline 1987 & 25.51 & 1.03 & 11.4 & 8.50 \\
\hline 1988 & 27.45 & 1.02 & 9.36 & 7.95 \\
\hline 1989 & 29.42 & 1.01 & 11.58 & 9.83 \\
\hline 1990 & 29.01 & 1.14 & 15.46 & 14.78 \\
\hline 1991 & 32.88 & 1.39 & 15.43 & 12.48 \\
\hline 1992 & 32.48 & 2.17 & 16.79 & 10.09 \\
\hline 1993 & 33.51 & 1.72 & 15.78 & 7.38 \\
\hline 1994 & 33.68 & 1.63 & 15.86 & 6.02 \\
\hline 1995 & 32.94 & 1.42 & 18.79 & 9.62 \\
\hline 1996 & 33.64 & 1.78 & 23.6 & 10.17 \\
\hline 1997 & 35.39 & 1.79 & 22.4 & 9.37 \\
\hline 1998 & 34.13 & 2.37 & 15.28 & 5.91 \\
\hline 1999 & 34.39 & 2.10 & 22.95 & 8.03 \\
\hline 2000 & 35.19 & 2.14 & 34.54 & 13.56 \\
\hline 2001 & 35.37 & 2.08 & 26.87 & 9.39 \\
\hline 2002 & 34.93 & 2.15 & 24.65 & 9.45 \\
\hline 2003 & 39.46 & 2.07 & 28.39 & 14.21 \\
\hline 2004 & 41.21 & 2.25 & 36.92 & 21.02 \\
\hline 2005 & 45.45 & 2.61 & 52.7 & 31.80 \\
\hline 2006 & 48.50 & 2.80 & 65.97 & 41.14 \\
\hline 2007 & 50.97 & 4.14 & 78.58 & 44.36 \\
\hline 2008 & 52.35 & 5.84 & 116.28 & 51.00 \\
\hline 2009 & 51.98 & 5.74 & 73.83 & 29.29 \\
\hline 2010 & 60.50 & 5.86 & 99.51 & 33.87 \\
\hline 2011 & 23.43 & 1.60 & 137.61 & 9.93 \\
\hline 2012 & 47.92 & 4.74 & 135.86 & 31.67 \\
\hline
\end{tabular}

Sources: See Appendix A.

Table 3. Descriptive statistics

\begin{tabular}{lcccc}
\hline Variable & Mean & Standard Deviation & Minimum & Maximum \\
\hline Ln Capital & 0.6879 & 0.4947 & 0.0010 & 1.7689 \\
Ln Labor & 7.4357 & 0.2077 & 7.0562 & 7.8671 \\
Ln Consumption & 11.0573 & 0.3014 & 10.4913 & 11.5220 \\
Ln Exports & 7.3739 & 0.6816 & 6.3816 & 8.7215 \\
\hline
\end{tabular}
$\mathrm{N}=33$.

Table 4. OLS estimates

\begin{tabular}{lcccc}
\hline Variable & Parameter & $\mathrm{t}$ Value & $\mathrm{Pr}>|\mathrm{t}|$ & Variance Inflation \\
\hline Intercept & $6.10836^{* * *}$ & 8.07 & $<.0001$ & 0 \\
Log Capital & $0.21694^{* * *}$ & 5.42 & $<.0001$ & 3.07106 \\
Log Labor & $0.11133^{*}$ & 1.95 & 0.0613 & 1.10141 \\
Log Consumption & $0.22397^{* * *}$ & 3.89 & 0.0006 & 2.35276 \\
Log Exports & $0.12571^{* * *}$ & 6.06 & $<.0001$ & 1.56416 \\
\hline
\end{tabular}

Significance: $* \mathrm{P}<0.10, * * \mathrm{P}<0.05, * * * \mathrm{P}<0.01$. 


\section{Conclusions}

The Libyan economy is heavily dependent on the oil sector, has the second largest proven oil reserves in the world, and is the leading oil producing country in Africa. The oil sector is the main source of income for all sectors of the Libyan economy. This study attempts to assess the relationship between economic growth, domestic consumption, labor, capital, and exports in Libya using time series data for the period 1980-2012. It was important to determine the factors affecting GDP growth, because increasing GDP results in an increased standard of living and a decrease in the unemployment rate.

Estimating the relationship among these factors, provides policymakers and researchers with a better understanding of the Libyan economy and a basis for developing plans and strategies for improving the standard living within the country. While increased exports and consumption have a positive effect on the Libyan economy; policy makers should also consider different policies to rationalize domestic fuel consumption and encourage the private sector to contribute to the activities of the oil sector.

While the current political situation in Libya is extremely difficult, it is important to consider these factors in future planning as the country hopefully moves beyond the current state of turmoil and conflict. Whenever this occurs, oil will play a lead role in the growth and development of a strong and stable economy. It is also essential that future oil revenue be invested to promote overall economic growth and economic development.

\section{References}

Adebipe, B. (2004). The impact of oil on Nigeria's economic policy formulation. Paper presented at the Conference on Nigeria: Maximizing pro-poor growth: Regenerating the Socio-economic Database, pp. 16-17.

Adjemian, S., Langot, F., \& Rojas, C. (2010). How do labor market institutions affect the link between growth and unemployment: The case of the European countries. The European Journal of Comparative Economics, 7(2), 347-371.

Akram, M., \& Mortazavi, R. (2011). Do crude oil price changes affect economic growth of India, Pakistan and Bangladesh? A multivariate time series analysis. Economics D-Level Thesis, HOGSKOLAN DALARNA.

Ali, I., \& Harvie, C. (2013). Oil and economic development: Libya in the post-Gaddafi era. Economic Modeling, 32, 273-285. (http://dx.doi.org/10.1016/j.econmod.2013.01.022)

Alimi, S. R., \& Muse, B. O. (2013). Export - led growth or growth - driven exports? Evidence from Nigeria. British Journal of Economics, Management \& Trade, 3(2), 89-100. http://dx.doi.org/10.9734/BJEMT/2013/2386

Amadi, C. R., \& Amadi, N. N. (2014). Analysis of energy balance on Nigeria's economic growth: Evidence on electricity sector: 1970-2010. European Journal of Business and Management, 6(26), 181-189.

Asafu-Adjaye, J. (2000). The relationship between energy consumption, energy prices and economic growth: Time Series Evidence from Asian Developing Countries. Energy Economics, 22(6), 615-625. http://dx.doi.org/10.1016/S0140-9883(00)00050-5

Berument, H. B., Ceylan, N. B., \&Dogan, N. (2010). The Impact of Oil Price Shocks on the Economic Growth of Selected MENA1 Countries. The Energy Journal, 31(1), 149-178. http://dx.doi.org/10.5547/ISSN0195-6574-EJ-Vol31-No1-7

Dada, E. A. (2011). Resource management and food insecurity in Nigeria. Journal of Economics and Sustainable Development, 2(5), 28-44.

Dallago, B. (2013). Financial and real crisis in the Eurozone and vulnerable economies. The European Journal of Comparative Economics, 10(3), 295-315.

Doğrul, H. G., \& Soytas, U. (2010). Relationship between oil prices, interest rate, and unemployment: Evidence from an emerging market. Energy Economics, 32, 1523-1528. http://dx.doi.org/10.1016/j.eneco.2010.09.005

EIA. (2013). U.S. Energy Information Administration. Libya analysis brief", independent statistics and analysis. Retrieved October 3, 2016 from http://www.eia.gov/countries/country-data.cfm?fips=LY

EIA. (2014). U.S. Energy Information Administration. Demand: Non-OECD. Retrieved October 3, 2016 from http://www.eia.gov/finance/markets/demand-nonoecd.cfm

Gbadebo, O. O., Olusegun, O., \& Chinedu, O. (2009). Does energy consumption contribute to economic performance? Empirical evidence from Nigeria. Journal of Economics and International Finance, 1(2), 044-058. 
Karanfil, F. (2008). Energy consumption and economic growth revisited: Does the size of unrecorded economy matter? Energy Policy, 36(8), 3029-3035. http://dx.doi.org/10.1016/j.enpol.2008.04.002

Kiria, A. R. (2013). The factors affecting gross domestic product (GDP) in developing countries: The Case of Tanzania. European Journal of Business and Management, 5(4), 148-158.

Kutner, M., Nachtsheim, C., Neter, J., \& Li, W. (2004). Applied linear statistical models (5th ed.). McGraw Hill Irwin.

Lee, C. C. (2005). Energy Consumption and GDP in developing countries: A cointegrated panel analysis. Energy Economic, 27(3), 415-427.

Mahadevan, R., \& Asafu-Adjaye, J. (2007). Energy consumption, economic growth and prices: A reassessment using panel VECM for developed and developing countries. Energy Policy, 35(4), 2481-2490. http://dx.doi.org/10.1016/j.enpol.2006.08.019

Maneschiold, P. (2008). A note on the export-led growth hypothesis: A time-series approach. Cuadernos de Economía, 45(132), 293-302. http://dx.doi.org/10.4067/S0717-68212008000200006

Mehrara, M., \&Firouzjaee, B. A. (2011). Granger causality relationship between export growth and GDP growth in developing countries: Panel co-integration approach. International Journal of Humanities and Social Science, 1(16), 223-231.

Mills, R. M. (2008). The myth of the oil crisis: Overcoming the challenges of depletion, geopolitics, and global warming. Praeger Publishers, United States of America Press.

Nkomo, J. C. (2006). The impact of higher oil prices on southern African countries. Journal of Energy in Southern Africa, 17(1), 10-17.

Noor, S., \& Siddiqi, M. W. (2010). Energy consumption and economic growth in South Asian countries: A co-integrated panel analysis. World Academy of Science, Engineering and Technology, 4(7), 196-201.

Odularu, G. O. (2008) Crude oil and the Nigerian economic performance. Oil and Gas Business. Retrieved October 3, 2016 from http://www.ogbus.ru/eng/authors/Odularo/Odularo_1.pdf

Romar, P. M. (1986). Increasing returns and long-run growth. Journal of Political Economy, 94, 1002-1037.

Salah, A. (1990). The effects of changes in the international oil market on the Libyan economy. Journal of Energy and Development, 15(2), 299-314.

Sari, R., \& Soytas, U. (2007). The growth of income and energy consumption in six developing countries. Energy Policy, 35(2), 889-898. http://dx.doi.org/10.1016/j.enpol.2006.01.021

Shaari, M. S., Hussain, N. E., \& Ismail, M. S. (2013). Relationship between energy consumption and economic growth: Empirical evidence for Malaysia. Business Systems Review, 2(1), 17-28.

Shirazi, N. S., \& Manap, T. A. (2005). Export-led growth hypothesis future econometric evidence from South ASIA. The Developing Economies, XLIII(4), 472-488.

Sultan, Z. A., \& Haque, M. I. (2011). The estimation of the cointegration relationship between growth, domestic investment and exports: The Indian economy. International Journal of Economics and Finance, 3(4), 226-232. http://dx.doi.org/10.5539/ijef.v3n4p226

Vohra, R. (2001). Export and economic growth: Further time-series evidence from less-developed countries. International Journal in Economic Research, 7(3), 345-350. http://dx.doi.org/10.1007/BF02295403

Yanagisawa, A. (2012). Impact of rising oil prices on the macro economy. The Institute of Energy Economics, Japan - IEEJ, Mayo. Retrieved February 8, 2017 from https://eneken.ieej.or.jp/data/4338.pdf

YCharts. (2016). Libya crude oil production. (Monthly, Barrels per Day) - YCharts. Retrieved October 3, 2016 from https://ycharts.com/indicators/libya_crude_oil_production

Yuan, J. H., Kang, J. G., Zhao, C. H., \& Hu, Z. G. (2008). Energy consumption and economic growth: Evidence from China at both aggregated and disaggregated levels. Energy Economics, Technology Change and the Environment, 30(6), 3077-3094. http://dx.doi.org/10.1016/j.eneco.2008.03.007

\section{Appendix A}

\section{Data Sources for Tables 1 and 2.}

Index Mundi. (2014). Libya Oil Exports, for 1980-2010. http://www.indexmundi.com/libya/oil_exports.html UN, 
2013.

EIA U.S. Energy Information Administration 2013. Export, Thousand per Day. International Energy Statistics, for 2011-2012.

http://www.eia.gov/cfapps/ipdbproject/iedindex3.cfm?tid=5\&pid=5\&aid=2\&cid=CG9,\&syid=1990\&eyid=2012

\&unit=TBPD Index Mundi, 2014. Libya Oil Exports, for 1980-2010. http://www.indexmundi.com/libya/oil_exports.html

UN, 2013. Exchange Rate. http://unstats.un.org/unsd/snaama/resQuery.asp

OPEC, Exchange rate- different years-annual statistical bulletin. http://www.opec.org/opec_web/en/publications/202.htm

Libyan Central Bank, Exchange Rate. Economics Report-Various Issues. http://www.cbl.gov.ly/eg/

OPEC. Libyan oil price- - different years-annual statistical bulletin. http://www.opec.org/opec_web/en/publications/202.htm

Libyan Central Bank, Oil Price. Economics Report, Various Issues.

EIA. 2013. U.S. Energy Information Administration, Local Consumption, Thousand per Day. International Energy Statistics.

http://www.eia.gov/cfapps/ipdbproject/iedindex3.cfm?tid=5\&pid=5\&aid=2\&cid=CG9,\&syid=1990\&eyid=2012 \&unit=TBPD

United Nations.2013. Population, National Accounts Main Aggregates Database. Basic Data Selection. http://unstats.un.org/unsd/snaama/selbasicFast.asp

Index Mundi, 2013.Labor Force, from 1997-2011. http://www.indexmundi.com/g/g.aspx?c=ly\&v=72

The World Bank, 2015. Labor force, total. http://data.worldbank.org/indicator/SL.TLF.TOTL.IN For labor force years 1980-1996 and 2012, General Information Authority, Statistic population, Libya, Different issues, http://gia.gov.ly/

Central Bank of Libya, Annual Economic Report, Various Issues, Labor Force for 2012, 1980-1996. http://www.cbl.gov.ly/eg/

EIA, 2013. Oil Production, US. Energy Information Administrative http://www.eia.gov/cfapps/ipdbproject/iedindex3.cfm?tid=5\&pid=53\&aid=1\&cid=CG9,\&syid=1980\&eyid=201 2\&unit=TBD

United Nations. 2014. GDP, at Current Prices, National Accounts Main Aggregates Database. Basic Data Selection. http://unstats.un.org/unsd/snaama/selbasicFast.asp

United Nations. 2014. GDP, at Constant 2005 Prices, National Accounts Main Aggregates Database. Basic Data Selection. http://unstats.un.org/unsd/snaama/selbasicFast.asp

EIA. United States Energy Information Administration, Average cost of Barrel Oil Production. Different Reports, http://www.eia.gov/finance/reports.cfm

EIA United States Energy Information Administration, Average cost of Barrel Oil Production. For years 1980-1989, the researcher divides the total production cost on the total production to get production cost per barrel. http://www.eia.gov/cfapps/frs/frstables.cfm?tableNumber=18\&startYear=1977\&endYear=2009\&loadAction=Ap ply+Changes

Average cost of Barrel Oil Production of the years 2010, 2011, and 2012 were estimated based on by the average of 2008 and 2009 due to a lack of published data available.

Inflation - GoCurrency.com- http://www.gocurrency.com/countries/libya. For the inflation during 2011 and 2012, we used an average of 2008, 2009, and 2010.

\section{Copyrights}

Copyright for this article is retained by the author(s), with first publication rights granted to the journal.

This is an open-access article distributed under the terms and conditions of the Creative Commons Attribution license (http://creativecommons.org/licenses/by/4.0/). 